continent. Work on the development of an accurate automatic method of measuring evaporation from natural surfaces, including growing crops, has reached an advanced stage. Measurements of the size and concentration of droplets in maritime and continental eumuli have shown that the droplet-concentration is systematically higher in continental cumuli, and further tests on artificial rain formation indicate that if seeding with silver iodide is to succeed the particles must be generated under conditions which ensure that they reach the supercooled regions of the atmosphere as soon as possible after release.

\section{NATIONAL INSTITUTE FOR RESEARCH IN DAIRYING}

\section{REPORT FOR 1956}

$I^{\mathrm{N}}$

$\mathrm{N}$ these eventful times, when so much is heard of atomic research and nuclear power, it is all too easy to forget that the production of good-quality food in amounts that will meet the needs of the world's ever-increasing population is one of the most important problems on which intensive scientific research is still urgently required. With this in mind, it is cheering to turn to the annual report of the National Institute for Research in Dairying, and to realize that so much work is being done on the production, properties and utilization of milk and milk products, and that so much detailed study is being made in the various sciences on which the dairy industry in all its many branches closely depends.

The Institute was founded forty-five years ago, and even a cursory glance at the report for $1956^{*}$ is sufficient to show what marked progress it has made in recent years, and how clearly the action of those who founded it at Reading in 1912 has been justified. The total number on the staff in 1956 exceeded three hundred, more than one hundred of whom were graduates in one or other of the many branches of science. The Institute now has eight principal departments, covering dairy husbandry, feeding and metabolism, physiology, nutrition, bacteriology, chemistry, physics and engineering. In addition, there are sections that deal specifically with isotopes and statisties, and a unit the duty of which is to maintain liaison with the dairy industry.

In the foreword of the report more than four pages are devoted to a very brief but highly informative outline of some recent investigations. The reader who wants to know at a glance what the Institute does, how its work adds to existing knowledge and how its findings apply to the dairy industry will find this short section particularly valuable. For the more leisurely reader this part of the report is followed by more than a hundred pages in which an account is given of the work of each of the main departments and units. Finally, for those who may be working in allied fields of research or who may require full details, a list of the Institute's recent publications is given with titles and references. More than 150 papers are cited in the list, most of which were published in 1956.

* National Institute for Research in Dairying: University of Reading. Report, 1956. Pp. 158. (Shinfleld : National Institute for Research in Dairying, 1957.)
Many of the problems under investigation are likely to give results of immediate importance in some branch of the dairy industry. Such, for example, are the studies that are being made of the milking machine and the milking technique itself, the sterilization of milk bottles, the ripening of cheese in modern types of wrapping and the ultra-hightemperature sterilization of milk. But in addition to work like that on subjects of immediate practical importance, the Institute has for many years enjoyed a well-merited reputation for the excellence of its fundamental work, particularly in the physiology of lactation and in the realm of nutrition. Among the many topics that fall into this category, mention is made in the report of research on the biosynthesis of carbohydrate by mammary gland tissue for which glucose labelled with earbon-14 was used. This study has shown that the galactose required for lactose formation is made from glucose in the mammary gland itself, and that pyruvate is not a precursor of lactose. Another piece of fundamental work has shown that the two $\beta$-lactoglobulins of cow's milk differ in their crystal forms but have almost equal molecular weights. Yet another deals with the relations between the hormones oxytocin and prolactin in their influence on the mammary gland and on lactation. Statistical methods are being increasingly used in many of the Institute's investigations, and in the past year they have been applied to a variety of problems, such as manurial trials with kale and cabbage, pasture evaluation and the assay of prolactin.

It is good to know that in Britain, which at present produces only somo 40 per cent of its own food, so much research work of this high standard is in progress in problems related to the important industry of dairying.

\section{WESTERN EUROPEAN CO-OPERATION}

$T$ HE broadsheet "Designs for Europe" (No. 414, September 16, 1957), issued by Political and Economic Planning, follows two earlier broadsheets : No. 405 (December 17, 1956), which gave a summarized translation of Part 1 of the Spaak Report, dealing with the Common Market, in which are outlined the proposals for the merging of markets, the policy to be pursued for the common market, and the development and use of Europe's rosources ; and No. 412 (July 15, 1957), "Free Trade and Social Security". This broadsheet quotes the Government's view expressed in the White Paper, "A European Free Trade Area", that it was not considered essential, in order to achieve the degree of effective competition necessary for the functioning of the Free Trade Area, that agreement to remove the disparities between the social regulations in different countries should precede or be a necessary condition of the creation of such an Area; it also summarized social security policies in Europe and described national schemes in France, Germany, Italy and Sweden before considering the possibility of international action. The broadsheet points out that there was insufficient information for a final opinion on the effects of great oconomic integration on social security policies and vice versa and that further research was needed. 
"Designs for Europe" begins by reviewing the principal European organizations set up since the War-the Economic Commission for Europe, the Organization for European Economic Co-operation, Western European Union, the North Atlantic Treaty Organization, the Council of Europe, the European Coal and Steel Community, European Economic Community and the European Atomic Energy Commission. It then goes on to Britain's relations with Europe, and emphasizes the strong practical reasons for some rationalization of these organizations.

The concept of a single European Assembly to coordinate the activities, interests and objectives of all these varied and overlapping organizations is generally regarded as unworkable, but Political and Economic Planning suggests that it might be practicable on more limited fronts, particularly separate attempts to rationalize organizations concerned mainly with economic and military affairs, thus avoiding the difficulty of linking economic and military cooperation. It is suggested that the Consultative Assembly of the Council of Europe should become the Assembly of the Organization for European Economic Co-operation while continuing its present varied activities, and that this body might become the principal European economic assembly in which all Western European countries would meet. If a free trade area was established, the Organization for European Economic Co-operation would be the most appropriate body to control its work.

The most successful role of the Economic Com. mission for Europe is considered to be in furthering technical co-operation, and it is emphasized that, wherever possible, duplication of technical co-operation in other economic organizations should be avoided. No valid justification is seen for the continued separate existence of the North Atlantic Treaty Organization and Western European Union, and it is suggested that the Assembly of the latter body might be widened into a North Atlantic Treaty Organization assembly. European co-operation, PEP concludes, is in danger of becoming ineffective, through lack of co-ordination. The whole pattern of European co-operation would be simplified by creating out of existing organizations a general economic and defence assembly for the West.

\section{TORNADOES IN GREAT BRITAIN}

$\mathrm{T}$

HE tornado is a relatively thin, roughly vertical

column of air rotating at very high speed about a central axis in which the pressure is markedly less than in the surrounding air. The reduction of pressure leads to condensation of water vapour in the inflowing air to produce a cloud along the axis of the tornado, shaped roughly like a giant elephant's trunk. In its more intense forms the tornado is the most violent and destructive of small-scale meteorological phenomena. The damage produced is caused. by the direct battering of the high wind, the twisting effect of the very great shear of wind outwards from the axis, the lifting effect of the intense vertical currents along the axis and the explosive effect of the sudden reduction of pressure as the axis crosses buildings. The tornado moves with the general wind-current, causing damage where it touches the ground along a track ranging from a few feet to a hundred yards in width. Tornadoes are always associated with heavy thunderstorms, and the rotation is clearly a dynamical phenomenon associated with convergence of air flow towards an axis, but a fully satisfactory theory explaining all their properties has not yet been produced.

The central plains of the United States in spring suffer more than anywhere else from tornadoes, probably because contrasts between adjacent air masses-in that region and season between air from the Gulf of Mexico and air from the Arctic north of America - are sharper than elsewhere and so produce more intense convection.

In the British Isles destructive tornadoes are comparatively infrequent. An examination of published reports showed a total of fifty-four in the eighty-three years from 1868 to 1950 , and most of these caused only minor damage. However, on May 21, 1950, there formed over the north-west part of the Chilterns a tornado which was more violent than most of those which cause damage in the United States.

This tornado is comprehensively described by Mr. H. H. Lamb in Meteorological Office Geophysical Memoir, No. 99*. Mr. Lamb and Mr. J. Simmonds, then both of the Central Forecasting Office, Dunstable, which was close to the track, made a thorough investigation of the tornado in the days immediately following it. The tornado was first noticed near Wendover, Buckinghamshire, at the western end of the Misbourne Valley, whence it moved north-east. ward to the Fen country, causing serious damage in places where it touched the ground. The place worst affected was Linslade, where damage to the value of $£ 25,000$ occurred. Sheets of corrugated iron were carried for half a mile through the air. The great reduction of pressure in the centre is shown by the fact that it lifted water in a duckpond to a height of $10 \mathrm{ft}$., which affords a rough estimate of the reduction of pressure as about one-third, since the height of the water barometer near sea-level is about $30 \mathrm{ft}$. The only known photograph, reproduced in the Memoir, of a tornado in Britain was taken by an airman at the R.A.F. Station at Halton as this one passed over.

The Memoir gives a full account of the meteorological situation and, from the damage to trees and from winds recorded by anemometers a mile or so from the track, of the structure of the tornado. Mr. Lamb points out that the first tornado and its regenerations occurred at the openings of valleys at right angles to the general wind, where there would be an initial curving of flow to stimulate the spin. The sense of rotation in this instance appears to have been cyclonic (counterclockwise), but this is not always so and a tornado of anticyclonic rotation has since occurred in France (La Météorologie, Paris, 317 ; 1955).

A comparison of the observations with the theories of causes of tornadoes is given. The Memoir concludes with a note on the climatology of tornadoes in Britain which clearly exhibits the correspondence of areas of maximum frequency of both thunderstorms and tornadoes.

It is interesting to note that on the thundery, squally afternoon of December 8,1954 , there was a sharp tornado to the west of London which caused severe damage along a line from Chiswick through Acton to Golders Green. A description with a radar. photograph is given in the Meteorological Mayazine, 84,$320 ; 1955$.

* Air Ministry : Meteorological Office. Geophysical Memoirs, No. 99 Tornadoes in England, May 21,1950 . By H. H. Lamb. Pp. $\mathbf{i}+38+$ 